with chloroform beforehand. In intact nerve, however, stained with the same solution without prior treatment with chloroform, only the cell borders of the endothelial barrier can be seen after the same interval. In these circumstances, between 70 and $90 \mathrm{~min}$. must elapse before the endothelial barrier is passed, and nodes of Ranvier begin to show.

It is concluded, therefore, that somatic nerves of frogs, dogs, rabbits and cats are surrounded by an endothelium-like double membrane. Its endothelial layers constitute a definite barrier to the diffusion of silver nitrate.

I wish to thank Prof. A. von Muralt, of Berne, for giving me facilities for this investigation and for his continued interest and advice, Prof. J. M. Yoffey, of Bristol, for assisting with the translation of this communication into English, and the Deutsche Forschungsgemeinschaft for financial support. HaNS Joachim LeHMaNN

Physiological Institute,

University of Berne. July 31.

${ }^{1}$ Lorente de No, R. "A Study of Nerve Physiology", I and II Stud. Rockefeller Inst, 131 and 132 (1947).

2 Lorente de No, R., J. Cell. and Comp. Physiol., 35, 195 (1950).

${ }^{3}$ Lorente de Nó., R., J. Gen. Physiol., 35, 145 (1952).

4 Lorente de No, R., J. Gen. Physiol., 35, 182 (1952).

${ }^{5}$ Rice, I. H., and Davis, H., Amer. J. Physiol., 87, 73 (1928).

6 Feng, T. P., and Gerard, R. W., Proc. Soc. Exp. Biol. Med., 27, 1073 $(1930)$.

7 Feng, T. P., and Liu, Y. M., J. Cell. and Comp. Physiol., 34, 1 (1949),

${ }^{8}$ Huxley, A. F., and Stämpfli, R., J. Physiol., 112, 496 (1951).

- Crescitelli, F., Amer. J. Physiol., 166, 229 (1951).

${ }^{10}$ Crescitelli, F., and Geisman, T. A., Amer. J. Physiol., 164, 509 (1951).

11 Aykut, R. Pfiügers Arch., 256, 19 (1952).

${ }^{12}$ Katz, B., Proc. Roy. Soc., B, 135, 506 (1948).

${ }^{13}$ Hodgkin, A. F., and Katz, B., J. Physiol., 108, 73 (1949).

14 Key, A., and Retzius, G., Arch. mikr. Anat., 9 (1873).

16 Ranvier, L. "Traité technique d'histologie" (Paris, 1875).

\section{A Soluble Form of Reconstituted Collagen}

IN attempting to repeat some experiments reported by von Buzagh ${ }^{1}$, it was noticed that the fibrous precipitate (Fig. 1), formed by adding a 10 per cent sodium chloride solution to a solution of calf Achilles tendon in 1.2 per cent acetic acid, dissolved in 0.9 per cent sodium chloride; on dialvsis of this solution, a fibrous precipitate was re-formed. In contradistinction, the precipitates obtained from solutions of tendon in acetic acid at concentrations more generally used $(0 \cdot 01-0 \cdot 4 \text { per cent })^{2}$ are insoluble in 0.9 per cent sodium chloride. The physical properties of reconstituted collagen thus vary according to the concentration of the acetic acid used for dissolving the original tendon.

Solution in 0.9 per cent sodium chloride occurred rapidly ; but examination of the material just before final solution revealed masses of tapered rod-like structures approximately $2-5 \mu$ in length, individual rods sometimes showing end-to-end aggregation (Fig. 2). In order to study the process of solution more closely, the precipitate obtained with 10 per cent sodium chloride was shaken with concentrations of sodium chloride varying from 0 to 5 per cent and examined microscopically. The fibre aggregates were first split longitudinally, so that in 2 per cent sodium chloride the precipitate consisted mainly of long fine filaments. Below this concentration the filaments appeared to be broken transversely into short rodlike structures.

In another experiment, sodium chloride to a final concentration of 1-5 per cent was added to aliquots

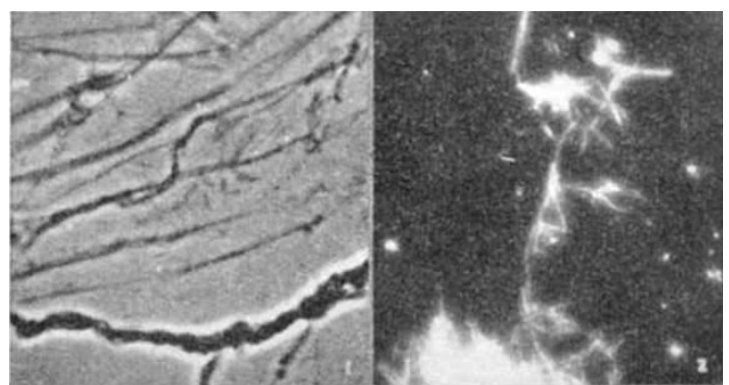

Fig. 1. Fibres obtained by 10 per cent sodium chloride 1.2 per selution of tendon in 1 . per cent acetic acl. Phase-

Fig. 2. Tapered rods formed collagen in 0.9 per cent sodium chloride. Dark ground illumination. $(\times 400)$

of a solution of tendon in 1.2 per cent acetic acid. With 1 per cent sodium chloride no precipitate was formed. With 1.5 per cent the precipitate was granular; at 2 per cent the precipitate contained granular material, long fine filaments and the rodlike structures; at $2 \cdot 5$ per cent and higher the precipitate was' wholly fibrous.

It seems likely that these different forms represent intermediate stages in the building up of the fibre aggregates, the granular material forming rod-like structures which link end to end to form long fine filaments, and that these in turn aggregate at right angles to their long axis to form the thicker fibres. The linkages must be weak since the fibres are easily broken up by 0.9 per cent sodium chloride solutions, first into filaments, then into rods, and finally going into solution. However, when chondroitin sulphate is used as the precipitating agent, the resulting fibres are insoluble in 0.9 per cent sodium chloride. If these fibres are incubated with hyaluronidase, which is known to break down chondroitin sulphate, they become soluble in 0.9 per cent sodium chloride with the intermediate formation of the rod-like structures. This suggests that chondroitin sulphate strengthens both the transverse and end-to-end linkages in this type of reconstituted collagen, and strengthens the evidence previously presented ${ }^{3}$ that chondroitin sulphuric acid is concerned in stabilizing the structure of tendon.

D. S. JACKSON

J. BALL

Rheumatism Research Centre,

University of Manchester, York Place,

Manchester 13. Aug. 18.

${ }^{1}$ v. Buzagh, A., Kolloidzschr., 101, 149 (1942).

2 Nageotte, J., C.R. Acad. Sci., Paris, 184, 115 (1927).

${ }_{3}$ Jackson, D. S., Biochem. J., 54, 638 (1953).

\section{Lævanpolyase}

SUCROSE in the culture of a lævan-forming microorganism might be converted into invert-sugar directly by invertase, or less directly by lævansucrase ${ }^{1}$ acting in conjunction with a lævan hydrolase ${ }^{2}$. An enzyme which does not cleave sucrose either hydrolytically or polymeratively and which hydrolyses a high polymer lævan has been designated 'Iævanpolyase', and has been separated by us from the culture fluids of two lævan-formers (Azotobacter 